\title{
A PENETRATION OF THE HISTORICAL THEORY OF POETIC TROPES: A PHENOMENOLOGICAL INVESTIGATION OF THE ICONIC HISTORICAL FIELD: A HERMENEUTIC STUDY
}

\section{Bob Troxell}

We are born to move, conceived and harbored in a prenatal world, sans weltenschauung, a world of fluid forces in which we develop tacit knowledge, molded by a mother's gestures, actions, breathings, movements through space and in love, beyond the ken of childhood reveries and Bachelardian poetic word space. We are born to move, to laugh, to cry, to run on impulse into an embrace of loved ones. We act in that process which shapes our perceptions and our lives.

Why is it that the intelligence of feeling, a range including the intelligence of feeling of R.W. Witkin, immaterial love bonds of apprenticeship discussed by Ken Beittel, and Anti-Stalinist tacit investigations of Michael Polanyi, why is it that this mode of understanding and investigation resides in the world of research as a second class citizen? Why has the distinction been made between the quantative and qualitative experiences of life? In part the blame resides in the conventionality of the word and language, a language which conveniently categorizes experience into the this or that, the hard soft of Bachelard's world. Gadamar leads us to an insight that perhaps is the key to iconic research when he concludes that hermeneutics may be linguistical, and that this linguisticality extends beyond mere grammar. Through language, meaning is reduced, not condensed as in poetry and poetic language as described by Herbert Read. This difference between poetry and prose is distance, a distance which creates filter upon filter, between the object, the viewer, and others in the community who are unwittingly parley to a fracus called academic philosophy and aesthetics. This safe state of Platonic freedom of slaves and ideal form attests to the bureaucratic embrace chilling the world, a world in love with runaway technology, the new Thantos. Heidegger, who refuses to distinguish between body and soul, the material and the immaterial, the named and the tacit, has thrown the field of contemplative philosophy a spitball (illegal in American Baseball). Heidegger surmises from a point of view in which action is the only point of view, the soul is the body, the body is the soul. This implicit collapse of categories is in a way a model for the unity consciousness Ken Wilber constructs which moves away from consciousness by reflection or distance. The amalgamation of these ideas gives rise to a new approach to interpretation and expression as a single event, a total incantation. For Sartre, desire brings about total and immediate union with the object of desire, but only through reflection is consciousness known. This incantation of images and objects, for Sartre and Ponge is rooted in the act of phenomenological writing. For Sartre and Dewey, consciousness is known by reflection, whereas Ponge experiences consciousness in the act of the presence-ing writing, a writing full of the "adventures of inexactitude". This Phenomenological Poetic writing, although closer to the depth historicality of one's experience, is still distanced and controlled by categories of words and names. Phenomenological inquiry has most often been expressed in the language of the named. This method does not begin to tap the deep well of consciousness in the total organism, the 
intelligence of the body and mind, the arabesque of body memory, imagination and poetic affirmation. Heidegger states "language speaks"; this is not enough the emphasis of his hermeneutics is still predicated on naming and calling. The rub is, how does one express and communicate in the linguistical mode without the use of name and call? How does one call the unnamed? Perhaps the answer lies in silence, an approach to interpretation which brackets out the chatter in the mind of the named. A phenomenological slash and burn results in a field of clear being, unencumbered by the "word".

As my colleague, Scott Meyer, mounts Ken Beittel's metaphorical winged centaur, body-mind steed, and spirits into the poetic imaginary realm of the word, I survey and analyze the impressions, the records of the hoof prints which record the hermeneutical leap, consciousness on the hoof. This consciousness is constructed by deed, not word, poetic in nature, the silent realm of disclosure freed from reflection, embracing the nowness of the nontranscendent now. This tack does present an impasse. How does one communicate poetic tacit or unnamed acts for pedagogic research? To bridge the bifurcation between the realm of the named and the tacit we look towards several established poetic, iconic, movement, and film theories for ground. It is with this confluence of theories and the ability of the video camera to record action that enables me to construct a model for the iconic mode of investigation.

Aside, spoken down stage, right, "Your mission, Mr. Phillips, if you decide to accept. .. will be to create a guide and taxonomy for the investigation of the tacit experience. This tape will self-destruct in six minutes!"

\section{Minute 1}

"The intelligent mechanic engaged in his job, interested in doing well and finding satisfaction in his handiwork, caring for his materials and tools with genuine affection, is artistically engaged"

$$
\text { Dewey (1934) }
$$

"VOICE OF THE PHILOSOPHER: Quaedam miracula universi. Mystice canorae, arcus crystallini, cirulatio corporum coelestium. Cyclorum epicyclorumque intoxicatio, intergritas tabulae chordarum et architectura elata globorum coelestium. GALLILEO: Shall we speak in everyday language? My colleague Mr. Federzoni does not understand. PHILOSOPHER: Is it necessary that he should? GALILEO: Yes. PHILOSOPHER: Forgive me. I thought he was your mechanic. ANDREA: Mr. Federzoni is a mechanic and a scholar. PHILOSOPHER: Thank you, young man. If Mr. Federzoni insists. . . GALILEO: I insist."

\section{Minute $\underline{2}$}

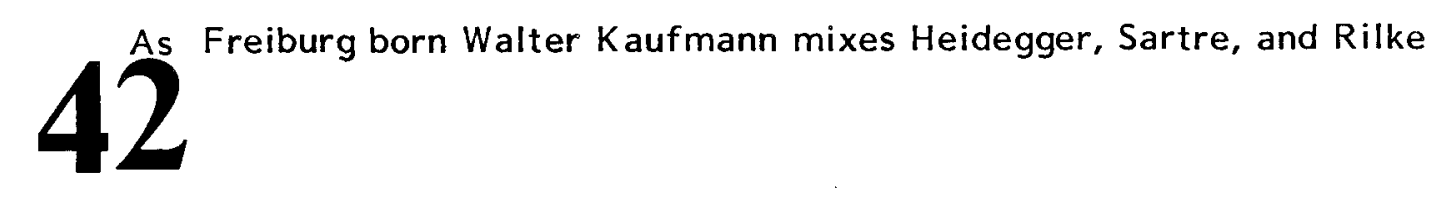


into the same existential bouillabaisse, a philosopher's stone soup, we become aware of the common flavor of their unique points of view. These individuals all had a great disdain for traditional philosophy, a philosophy remote from life; academic, and superficial. These writers, poets, artists, and thinkers, had at one point in time cut the cord with the traditional forms of academic continental philosophy. Somehow these rebels have been brought back into the fold and are shadowed by the umbrella of the current megalomanic phase of philosophy. It is as if these independent thinkers had invented a new game, Being, and used an old ball, phenomenological method, in a different light. As a child I recall the neighborhood bully treating the new kids on the block the same way; he allowed us to use his ball if we played his game his way. Fortunately, we have the bull by the all.

Method is a means to an end; by use of a method certain work is accomplished. With a hammer I can build a house, crack a walnut, kill my brother Caine if I am able; the choice is mine. To express any doubt that the tool, phenomenological method can only be used certain ways, for certain purposes, belittles the value of the tool. Perhaps the distinction must be drawn that a tool does not his master make and that the tool can be used in other methods of inquiry outside of the shadow of traditional continental philosophy. As a hammer is a tool to be used to work on various tasks, so too is phenomenological method.

\section{Minute 3}

"We measure rays, transform and utilize, and know their nature now more perfectly. But our conception of the force itself is handicapped by ancient forms of words and antique habits in our thoughts of "things", the handicap of three-dimensioned minds."

William Pallister (1931)

\section{Minute 4}

"The right tool for the right job, the right tool for the right job. Don't you ever use those good sewing scissors to open that paint can again!" , my father would admonish me. To which I would reply, "But gee, Dad, it worked." In my youth I was asked to do extraordinary tasks with ordinary tools. A point of a scissors inserted between the seam of the lid and the body of the can, when flexed, gave me access to the paint inside. Although I had not used the correct cutting edge for a proper task such as cutting silk or philosopher's tweed, the "improper" use of the tool got the job done. Somehow it appears to me that the phenomenological poetic methods used by Ponge and Bachelard fit the needs and match the spirit of the iconic or non-verbal mode of investigation. How is it that 1 might use the tip instead of the edge to pry open the iconic method? The tip, the point, is backed by an alignment of Gadamer's (Palmer, 1969) expansion of the definition of the hermeneutics based on a linguistical rather than a grammatical experience; Burke's (1969) body forth principle and Heidegger's concept of poetic dwelling. Once we align these three approaches we simply twist and pry. We are into the can of iconic ivestigation.

To clarify for one moment, I posit myself in an assumption that everything, contrary to some sophomoric belief, is not metaphor. It may be that the verbal and the iconic are related by family resemblances (Wittgenstein, 1953) or that 
as Foucault (1982) concludes in This Is Not A Pipe, there exists similitudes or similarities between image, text, and affirmation. Through this we understand that language and art are not the same, although they do have family resemblances. If the iconic is linguistical and the linguistical is poetic we must dive beyond the metaphor level into specific poetic behavior. Hayden White makes such distinctions in his analysis of the imaginative history written by Marx, Tocqueville, etc. White distinquishes between the various types of tropes (i.e. figures of speech) and the part whole relationships which categorize them as metaphor, metonomy, synedoche, and irony. He further speculates that the poetic style of an historical writing connotes political and social implications. Although White is analyzing specific poetic relationships, we also know that poetic language results from a body forth principle (Burke, 1969). It might be said that we move into the abstraction of poetic language. Because movement begets language and language remembers movement an analysis of poetic part whole relationships might carry over into interpretive language. Intepretive movement might be considered in terms of whole whole; part part; part whole; and negational or in other words metaphor, metonomy, synedoche, and irony.

Who has never seen a person engaged in front of a painting, deep in thought, slowly move their hips to echo a silent compositional thrust? This tacit knowledge, based on an iconic kinesthetic response has poetic qualities. It is this unconscious movement that must be brought to a conscious level and then analyzed. This awareness, the poetic dance of consciousness, may by White's analysis of poetic relationships have political and social implications. If we are engaged in a two way dialogue with a work of art rather than an acausal one-directional communication then by some definitions it is a social situation. Spence (1978) states, "Thus, if the ground of our knowledge is social. . . then epistomology is a political and sociological study rather than merely a psychological and philosophical one". Because the act of interpretation, the movement with or in concert with objects or events is an act of consciousness posited in the community and not the individual; the poetic act or movement becomes a political act and consequently a move from the individual and the psychological.

\section{Minute 5}

I have tried by outline and sequence to develop first, a break from traditional philosophy; second, justification of the use of a philosophical tool, phenomenological method in non-traditional ways; third, to remake that tool to fit the problem for analysis of iconic experience; fourth, to align poetic consciousness with the community of political action; and finally to bring you to the apparatus of recording the movements to justify and appease academic bureaucracy. Perhaps it is synchronism, perhaps influence, that as Ken Beittel prepares his manuscript East and West of the Great Tradition, I find in the East-West synthesis of technology and nature two writers who both suggest that the low definition of video may be the best technique to capture poetic-movement, poetic-consciousness.

"Because the low definition of TV insures a high degree of audience involvement, the most effective programs are those that present situations which consist of some process to be 
completed. Thus to use TV to teach poetry would permit the teacher to concentrate on the poetic process of actual making, making as it pertained to a particular poem. The book form is quite unsuited for this type of involved presentation."

$$
\text { Mc Luhan (1964) }
$$

As White analyzes the words of Marx, Toucquville, and other political writers, I scan the tube of low light illumination for the postic movement. It is quite ironic that in the East the quality of low definition is also critical to the poetic aesthetics found in the temples of Kyoto (Tanizaki, 1975).

"... so dark are these alcoves, even in the bright daylight that we can hardly discern the outlines of work. . . The lack of clarity, far from disturbing us, seems rather to suit the painting perfectly."

It appears that low definition and low light levels are requisite for poetic consciousness. Perhaps that is why this particular construction should not be done by a classical poet but rather by a poet who looks toward the moon, the true poet (Graves, 1975). By the light of the new moon, by the light of the TV, we pass into a new phase of research.

Minute 6

BOOM! My egg timer must be slow.

\section{REFERENCES}

Bachelard, Gaston. The Poetics of Reverie. Translated by D. Russell. Boston: Beacon Press, 1969.

Beittel, Kenneth. East and West of the Great Tradition. Tokoyo: Weatherhill, 1984.

Burke, Kenneth. A Rhetoric of Motives. Prentice Hall, 1950; reprint ed., Berkely: University of California Press, 1969.

Dewey, John. Art as Experience. New York: A Perigee Book, 1934.

Foucault, Michel. This is Not A Pipe. Berkely: University of California Press, 1982.

Graves, Robert. The White Goddess: A Historical Grammar of Poetic Myth. New York: McGraw-Hill, 1975.

Heidegger, Martin. Poetry, Lanquage, Thought. Translated by Albert Hofstadter. New York: Vintage Press, 1971.

Hummel, Ralph. The Bureaucratic Experience. 2nd. ed. New York: St. Martin's Press, 1982.

Innis, Harold A. The Bias of Communication. Forward by Marshall Mc Luhan. Toronto: University of Toronto Press, 1951.

Kaufmann, Walter. Existentialism From Dostoevsky to Sartre. New York: The World Publishing Co., 1956.

Mc Luhan, Marshall. Understanding Media: The Extensions of Man. New York: NcGraw-Hill, 1964.

Pallister, William. Poems of Science. New York: Playford Press, 1931.

Palmer, Richard E. Hermeneutics. Evanston: Northwestern University Press, 1969. 
Polanyi, Michael. The Tacit Dimension. New York: Doubleday and Company Inc., 1966.

Sartre, Jean Paul. Imagination a Psychological Critique. Translated by orrest Williams. Ann Arbor: University of Michigan, 1980.

Spence, Larry D. The Politics of Social Knowledge. University Park: The Pennsylvania State University Press, 1978.

Tanizaki, Jun'ichiro. In Praise of Shadows. New Haven: Leete's Island Book, 1977.

White, Hayden. Metahistory: The Historical Imagination in Nineteenth Century Europe. Baltimore: The John Hopkins University Press, 1973. 